\title{
A novel community of acidophiles in an acid mine drainage sediment
}

\author{
Chunbo Hao $\cdot$ Hongxun Zhang $\cdot$ Richard Haas $\cdot$ \\ Zhihui Bai · Baoguo Zhang
}

Received: 8 February 2006/ Accepted: 19 April 2006/ Published online: 2 June 2006

(C) Springer Science+Business Media B.V. 2006

\begin{abstract}
A sediment sample ( $\mathrm{pH}$ 2.5) was collected at an acid mine drainage site in Anhui, China. The present acidophilic microbial community in the sediment was studied with a $16 \mathrm{~S}$ rRNA gene clone library. Small-subunit rRNA genes were PCR amplified, cloned and screened by amplified rDNA restriction analysis (ARDRA). Subsequently, 10 different clones were identified and they were affiliated with Acidobacteria, $\beta / \gamma$-Proteobacteria, $\delta$-Proteobacteria, Nitrospira, Candidate division TM7, and Low G + C Grampositives. Phylogenetic analysis of $16 \mathrm{~S}$ rRNA gene sequences revealed a diversity of acidophiles in the sediment that were mostly novel. Unexpectedly, 16S rRNA gene sequences affiliated with $\delta$-Proteobacteria were found to constitute more than $60 \%$ of clone library. To our knowledge, this is the first occasion that bacteria of $\delta$-Proteobacteria have been found dominant in the acidic habitat. Anaerobic sulfate- or metal reduction is the predominant physiological trait of bacteria of this subdivision. The high sulfate, ferric iron and the presence of bioavailable carbon in the anaerobic microenvironment may result in the dominance of bacteria of $\delta$-Proteobacteria.
\end{abstract}

C. Hao $\cdot$ H. Zhang $(\bowtie) \cdot$ Z. Bai $\cdot$ B. Zhang

Research Center for Eco-Environmental Sciences,

Chinese Academy of Sciences, 100085 Beijing, China

e-mail: hxzhang@rcees.ac.cn

R. Haas · Z. Bai

Centre for Water Science and System,

University of South Australia, Mawson Lakes,

SA 5095, Australia

R. Haas

Australian Water Quality Center, Bolivar,

SA 5510, Australia
Keywords Acid mine drainage $\cdot$ Acidophile . Sediment $\cdot 16 \mathrm{~S}$ rRNA $\cdot$ Clone library

\section{Introduction}

A serious ecological problem caused by the mining industry is the occurrence of acid mine drainage (AMD). The mining wastewaters typically contain high levels of metals ions such as iron, copper, aluminum and manganese, as well as metalloids, of which arsenic is generally of greatest concern. AMD generates when metal sulphide minerals, particularly pyrite $\left(\mathrm{FeS}_{2}\right)$, come in contact with oxygen and water. The overall reaction can be written as followed: $\mathrm{FeS}_{2}+14-$ $\mathrm{Fe}^{3+}+8 \mathrm{H}_{2} \mathrm{O} \rightarrow 15 \mathrm{Fe}^{2+}+2 \mathrm{SO}_{4}^{2-}+16 \mathrm{H}^{+} ; \mathrm{Fe}^{3+}$ is the predominant oxidant at low $\mathrm{pH}$ and is usually the limiting reagent. The inorganic oxidation rate of ferrous ion $\left(\mathrm{Fe}^{2+}\right)$ below $\mathrm{pH} 3$ is slow. Acidophilic organisms, however, can generate energy by converting ferrous iron to ferric iron. Thus, the oxidation of pyrite and acidification of the AMD is greatly increased in the presence of iron-oxidizing species such as Acidithiobacillus ferrooxidans (Johnson 1998).

A. ferrooxidans is the best studied organism which catalyses the generation of AMD. Models have been proposed for its energetic characteristics and its role in pyrite dissolution. Many investigations have studied its iron-oxidizing and respiratory enzymes since its isolation in 1947 (Rawlings 2001; Rojas-Chapana and Tributsch 2001; Gonzalez-Toril et al. 2003). A. ferrooxidans has long been considered the main organism causing the extreme conditions of AMD systems. Only recent molecular ecology studies have shown that other iron-oxidizing microorganisms, e.g., Leptospirillum spp. 
and Ferroplasma spp., might be more important than $A$. ferrooxidans in the generation of acidic environments (Schrenk et al. 1998; Edwards et al. 2000; Golyshina et al. 2000).

Most AMD-related acidophilic microbes are sensitive to organic substances and grow only very slowly on solid medium. These traits render these bacteria very difficult to cultivate as pure cultures. Many workers have used the rRNA approach to detect microbial communities and to describe the structures of these communities in various environments without isolating the component microorganisms (Godon et al. 1997; Watanabe et al. 2000; Gomes et al. 2003).

These studies have shown that most $16 \mathrm{~S}$ ribosomal RNA gene sequences directly amplified from environmental samples are different from the sequences of comparable laboratory strains. It has been concluded from such observations that microbial diversity in the natural environment is much greater than the diversity of the bacteria that have been isolated (Orphan et al. 2001; Watanabe et al. 2002). The introduction of molecular biological techniques, such as clone libraries and denaturing gradient gel electrophoresis (DGGE), has produced significant advances in the field of microbial ecology (Hugenholtz et al. 1998).

Our field site at the Xiang Mountain, Anhui, China, comprises an AMD lake associated with a pyritedominated ore body. In this report we present a molecular characterization of the microbial diversity and composition of the acidic sediment taken from the site beside the acid lake. The results considerably extend our knowledge of the diversity of microorganisms in AMD environments.

\section{Materials and methods}

\section{Sample collection}

Sediment samples were collected from the AMD lake on Xiang Mountain (Anhui, China) on 6 August 2005. The site was on the bank of the lake, $5 \mathrm{~m}$ above the water level (Fig. 1). The samples were collected from the exposed sediment layer directly into a sterile container and kept below $4^{\circ} \mathrm{C}$ until processing within 2 days. Similarly, samples were taken from the adjacent waste ore. Field measurement of $\mathrm{pH}$ was carried out by $\mathrm{pH}$ meter (Thermo Orion, USA).

The moisture content of the sediment was obtained by drying ground sediment for 2 days at $105^{\circ} \mathrm{C}$. The elemental analysis was conducted by the Analytical and Testing Center, Beijing Normal University, using

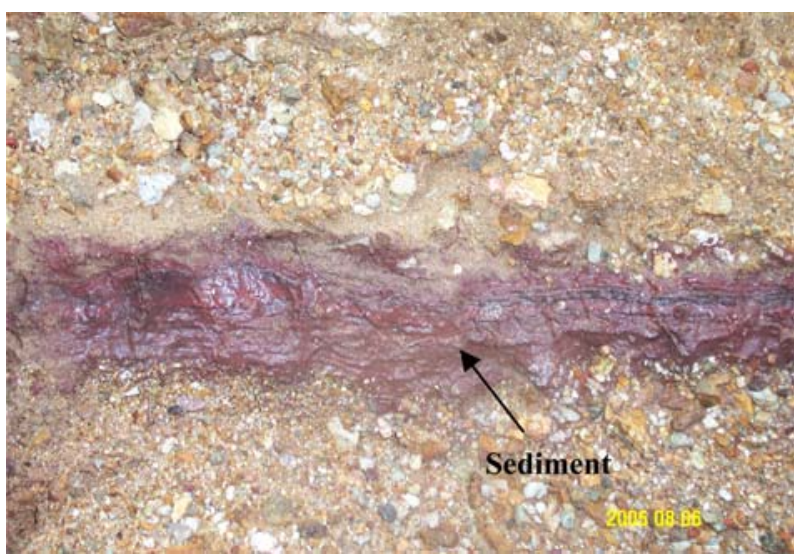

Fig. 1 The sampled brown-purple sediment layer

an Inductively Coupled Plasma Emission Spectrometer (JYl-ULTIMA, France).

DNA extraction and purification

The method used for extraction of nucleic acids from sediment were based on the protocol described previously (Zhou et al. 1996) and included initial wash steps to exclude iron and raise the $\mathrm{pH}$ prior to cell lysis. Extractions were performed on $1.5 \mathrm{~g}$ samples that were pelleted by centrifugation, washed twice with $5 \mathrm{ml}$ $0.02 \mathrm{M} \mathrm{H}_{2} \mathrm{SO}_{4}$ and then with $5 \mathrm{ml}$ STE buffer (sucrose $100 \mathrm{mg} / \mathrm{ml}$, Tris $\mathrm{HCl} 50 \mathrm{mM}$, EDTA $10 \mathrm{mM}, \mathrm{NaCl}$ $100 \mathrm{mM}, \mathrm{pH}$ 8.0). Subsequently, the samples were resuspended in $3 \mathrm{ml}$ DNA extraction buffer (sucrose $100 \mathrm{~g} / \mathrm{l}$, Tris $\mathrm{HCl} 50 \mathrm{mM}, \quad$ EDTA $10 \mathrm{mM}, \quad \mathrm{NaCl}$ $100 \mathrm{mM}, 10 \mathrm{~g} / \mathrm{l} \mathrm{CTAB}, \mathrm{pH} 8.0$ ), and $50 \mu \mathrm{l}$ lysosyme $(10 \mathrm{mg} / \mathrm{l})$ were added to the suspension, and this was incubated for $40 \mathrm{~min}$ at $37^{\circ} \mathrm{C}$. About $50 \mu \mathrm{l}$ Proteinase $\mathrm{K}$ $(10 \mathrm{mg} / \mathrm{ml})$ and $1 \mathrm{ml} 10 \mathrm{~g} / \mathrm{l} \mathrm{SDS}$ were added to the mixture, and this was incubated for $45 \mathrm{~min}$ at $50^{\circ} \mathrm{C}$. The supernatants were collected after centrifugation at $6,000 \times g$ for $10 \mathrm{~min}$ at room temperature and transferred into new centrifuge tubes. The cell lysates were extracted twice with an equal volume of chloroform: isoamylalcohol $(24: 1, \mathrm{vol} / \mathrm{vol})$. The nucleic acids were precipitated from the aqueous phase with 2 volume of ethanol at $-20^{\circ} \mathrm{C}$ for $2 \mathrm{~h}$. The pellet of nucleic acids was obtained by centrifugation at $12,000 \times g$ for $20 \mathrm{~min}$ at $4^{\circ} \mathrm{C}$, washed with ice cold $70 \%$ ethanol, and dissolved in $50 \mu \mathrm{l}$ sterile demineralized water.

\section{PCR and fractionation of 16S rRNA genes}

The 16S rRNA genes of the microbial community were amplified from the genomic DNA of the sediment with the primer pair 27f (5'-AGA GTT TGA TCM TGG 
CTC AG-3', M = C or A) and 1492r (5'-TAC GGY TAC CTT GTT ACG ACT T-3', Y = C or T) complementing positions 8 to 27 and 1510 to 1492 of Escherichia coli 16S rDNA (Kellner 2002). PCR cycling was performed with Applied Biosystem Gene Amp PCR system 2700. PCR amplification reaction conditions were as previously described (Sambrook and Russell 2001). PCR products were purified using EZ-10 spin column DNA Gel Extraction kit (BBI, Canada), quantified by ethidium bromide-u.v. detection on an agarose gel, ligated into the pGEM-T easy vector (Promega, USA). Then the resulting plasmids were transformed into E. coli DH5 $\alpha$ following the manufacturer's instructions.

ARDRA analysis and sequencing of inserted 16S rRNA genes

For amplified rDNA restriction analysis (ARDRA) and sequencing, the inserted fragment was amplified by PCR and template DNA was provided by contact of a small pipette tip with a colony of cloned host cells which were immersed in the PCR mixture. Primers for the PCR were the vector-specific T7 $\left(5^{\prime}\right.$ TAA TAC GAC TCA CTA TAG GGC-3') and SP6 (5'-ATT TAG GTG ACA CTA TAG AAT ACT C$\left.3^{\prime}\right)$. The PCR products were digested with two four-base-specific restriction enzymes ( $R s a$ I \& Msp I) (Toyobo, Japan). The procedure of restriction enzyme digestion of the unpurified PCR products and observation of restricted fragments were as previously described (Picard et al. 2000). ARDRA patterns were grouped, and representative cloned fragments were sequenced by BGI LifeTech Co., Ltd., China.

\section{Phylogenetic analysis}

The sequences obtained in this research were checked for chimeric artifacts by the check-chimera program of the Ribosomal Database Project (RDP). These sequences were also compared with 16S rDNA sequences deposited in public databases using the BLAST $^{\mathrm{TM}}$ search program. The $16 \mathrm{~S}$ rRNA gene sequences of various bacteria (including those closely related to the unknown sequences, as indicated by the BLAST search) obtained from the GenBank database were aligned with the new sequences by using Clustal $\mathrm{X}^{\mathrm{TM}}$. The phylogenetic tree was constructed by the neighbor-joining with robustness of 1000 bootstrapping using PHYLIP 3.65. Phylogenetic trees were viewed by Treeview ${ }^{\mathrm{TM}}$.
Nucleotide sequence accession numbers

Sequences reported in this paper have been submitted to GenBank with accession numbers from DQ328617 to DQ328626.

\section{Results}

\section{Sediment sample}

The naturally exposed surface of the sample site is shown in Fig. 1. The studied sediment layer was of brown-purple color and approximately $10-\mathrm{cm}$ thick. The adjacent khaki waste ore was predominantly derived from a pyrite-dominated ore body. The moisture content of the sediment was $30 \%(\mathrm{w} / \mathrm{w})$, and its $\mathrm{pH}$ was 2.5. The $\mathrm{pH}$ of the nearby AMD is 2.2, and metal ion concentrations lie above $10 \mathrm{~g} / \mathrm{l}$.

The element composition analysis of (i) the sediment and (ii) the adjacent waste ore showed that the iron content in the sediment was 3.5 times higher than in the waste ore (Table 1).

\section{Cloning and sequencing}

The bacterial community in the sediment was characterized by ligating the PCR product of an almost fulllength 16S rDNA into a cloning vector. Then 100 clones were selected from the generated clone library. The results of the in-situ-PCR indicate that 85 of the 100 chosen clones had inserted fragments of the correct size.

Cloned inserts were amplified by PCR and digested with restriction enzymes. ARDRA banding patterns were clearly distinguishable. The 85 clones could be grouped into 15 distinct ARDRA patterns. Representatives of each group were sequenced. Sequence similarity then reduced the ARDRA groups to 10 representative sequences (Table 2). None of the sequences were judged to be a chimera.

\section{Phylogenetic analysis of $16 \mathrm{~S}$ rDNA}

A neighbor-joining tree was constructed with these sequences and related sequences in the databases (Fig. 2). Clone H6, H24 and $\mathrm{H} 65$ were related to $\beta / \gamma$ Proteobacteria and represented $13.2 \%$ of total clones. Clone $\mathrm{H} 65$ has a $99 \%$ similarity to $A$. ferrooxidans and was clustered with it in the phylogenetic tree. Clone H6 and H24 had little similarity to known sequences (95 and $92 \%$ respectively) and most of the related sequences originated from environmental samples. 
Table 1 The elemental composition of the sediment and adjacent waste ore ( $\%$ in $w / w)$

\begin{tabular}{lcl}
\hline Sample & Sediment & Waste ore \\
\hline Fe (\%) & 29.18 & 8.30 \\
Mn (\%) & 0.04 & 0.02 \\
$\mathrm{Ca}(\%)$ & 0.32 & 0.09 \\
$\mathrm{Al}(\%)$ & 1.09 & 1.25 \\
$\mathrm{Na}(\%)$ & 0.66 & 1.51 \\
$\mathrm{~K}(\%)$ & 0.49 & 0.98 \\
$\mathrm{~S}(\%)$ & 0.44 & 0.34 \\
\hline
\end{tabular}

The most abundant clone type (51.1\% of total clones) was affiliated with $\delta$-Proteobacteria, represented by clone H11. This is surprising, as most known Proteobacteria found in acidic environment belong to the $\beta / \gamma$-subdivision; only Bond et al. (2000) found small quantities of $\delta$-Proteobacteria in acidic slime. To our knowledge, this is the first occasion that $\delta$-Proteobacteria were found as a major group in such an acidic habitat. After the phylogenetic analyses, it was not possible to affiliate the clone sequence with any particular representatives of the subdivision. It only clustered with $\mathrm{H} 74$, the other clone related to $\delta$-Proteobacteria in this study and the two clones that Bond et al. (2000) have found (Fig. 3).

Clones $\mathrm{H} 12$ and $\mathrm{H} 50$ were positioned firmly in the Nitrospira group and had $97 \%$ similarity to the closest relatives. The two types of clone did not cluster with Leptospirillum ferrooxidans and L. ferriphilum, but formed a monophyletic group (Fig. 2). Previously, phylogenetic analysis of Leptospirillum sequences defined two groups, denoted as group I and group II (Edwards et al. 1999). Bond et al. found a new type of sequences that had only $89-93 \%$ similarity to sequences from both Leptospirillum groups I and II when they studied acidophiles in a lithotrophic biofilm at an acid mine drainage site (Bond et al. 2000). Therefore, these sequences were defined as Leptospirillum group . After further phylogenetic analyses (Fig. 4), we found both clone H12 and H50 can only cluster with the sequence found by Bond, thus they should belong to Leptospirillum group.

Clone H5 was affiliated with Acidobacteria, having $94 \%$ similarity to its closest relative, and the related sequences were mostly from uncultured bacteria. Acidobacteria are heterotrophic acidophiles and usually present in acidic environment. They utilize organic compounds such as cell exudates and lysates originating from the autotrophic primary producers. They form communal associations with autotrophic acidophiles by "detoxifying" the environment for the latter group, which is more sensitive to organic substances (Johnson 1998).

Clone H70 was clustered with Low G + C Grampositives, having $97 \%$ similarity to its closest relative. As most Low $\mathrm{G}+\mathrm{C}$ Gram-positives bacteria are

Table 2 BLAST analysis of $16 \mathrm{~S}$ rDNA sequences of acidophiles in the sediment

\begin{tabular}{|c|c|c|c|c|c|}
\hline $\begin{array}{l}\text { Representative } \\
\text { sequence }\end{array}$ & $\begin{array}{l}\text { Length } \\
\text { (bp) }\end{array}$ & Frequency & $\begin{array}{l}\text { Microbial } \\
\text { group } \\
\text { affiliation }\end{array}$ & $\begin{array}{l}\text { Closest relative } \\
\text { (Genebank } \\
\text { accession number) }\end{array}$ & Similarity \\
\hline H5 & 1461 & $4.4 \%$ & Acidobacteria & $\begin{array}{l}\text { Uncultured bacterium } \\
\text { (AB179509) }\end{array}$ & $1378 / 1462(94 \%)$ \\
\hline H6 & 1494 & $4.4 \%$ & $\gamma$-Proteobacteria & $\begin{array}{l}\text { Uncultured bacterium clone } \\
\text { 1013-28-CG34 (AY532575) }\end{array}$ & $1423 / 1492(95 \%)$ \\
\hline H11 & 1517 & $51.1 \%$ & $\delta$-Proteobacteria & $\begin{array}{l}\text { Uncultured bacterium BA71 } \\
\text { (AF225447) }\end{array}$ & $1418 / 1451(97 \%)$ \\
\hline H12 & 1521 & $6.7 \%$ & Nitrospira & $\begin{array}{l}\text { Uncultured bacterium clone } \\
\text { ASL9 (AF544226) }\end{array}$ & 1476/1515 (97\%) \\
\hline $\mathrm{H} 24$ & 1502 & $4.4 \%$ & $\beta$-Proteobacteria & $\begin{array}{l}\text { Uncultured bacterium clone } \\
\text { DSBACT9 (AY762628) }\end{array}$ & $1030 / 1109(92 \%)$ \\
\hline $\mathrm{H} 40$ & 1432 & $2.2 \%$ & Candidate Division TM7 & $\begin{array}{l}\text { Uncultured soil bacterium clone } \\
\text { C129 (AF507687) }\end{array}$ & $1297 / 1411(91 \%)$ \\
\hline H50 & 1520 & $6.7 \%$ & Nitrospira & $\begin{array}{l}\text { Uncultured bacterium } \\
\text { (DQ223212) }\end{array}$ & $1473 / 1517(97 \%)$ \\
\hline H65 & 1500 & $4.4 \%$ & $\gamma$-Proteobacteria & $\begin{array}{l}\text { Acidithiobacillus ferrooxidans } \\
\text { strain QXS-1 (DQ168465) }\end{array}$ & 1491/1498 (99\%) \\
\hline $\mathrm{H} 70$ & 1491 & $2.2 \%$ & $\begin{array}{l}\text { Low } \mathrm{G}+\mathrm{C} \\
\text { Gram-positives }\end{array}$ & $\begin{array}{l}\text { Uncultured Low } \\
\text { G + C Gram-positive bacterium } \\
\text { (DQ223211) }\end{array}$ & $782 / 799(97 \%)$ \\
\hline H74 & 1484 & $13.3 \%$ & $\delta$-Proteobacteria & $\begin{array}{l}\text { Uncultured bacterium BA71 } \\
\text { (AF225447) }\end{array}$ & $967 / 992(97 \%)$ \\
\hline
\end{tabular}




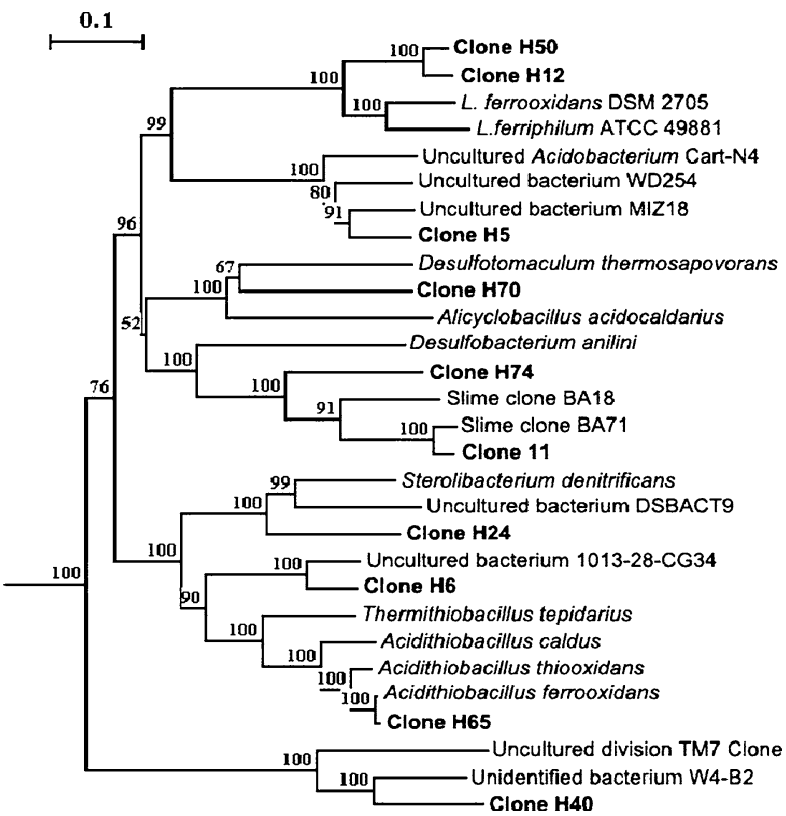

Fig. 2 Neighbour-joining phylogenetic tree from analysis $1.5 \mathrm{~kb}$ of 16S rRNA gene sequence of clones obtained from acidic sediment and related sequences. Numbers at the node indicate bootstrap values of 1000 resampling. Cyclobacterium marinum strain DSM 745 was used as outgroup (not shown). The scale bar represents changes per nucleotide. Database sequence accession numbers are as follows: L. ferrooxidans DSM 2705, X86776; Leptospirillum ferriphilum strain ATCC 49881, AF356829; Uncultured Acidobacterium Cart-N4, AY118153; Uncultured bacterium MIZ18, AB179509; Desulfotomaculum thermosapovorans, Y11575; Alicyclobacillus acidocaldarius, AY573796; Dsulfobacterium aniline, AJ237601; Slime cline BA18, AF225446; Slime cline BA71, AF225447; Steriolibacterium denitrificans, AJ306683; Uncultured bacterium DSBACT9, AY762628; Uncultured bacterium 1013-28-CG34, AY532575; Thermithiobacillus tepidarius, AJ459801; Acidithiobacillus caldus, Z29975; Acidithiobacillus thiooxidans, AJ459803; Acidithiobacillus ferrooxidans, DG168465; Uncultured division TM7 clone, AY792306; Unidentified bacterium W4-B2, AY345503

heterotrophic as well, $\mathrm{H} 70$ may play a role as decomposer in acidic ecosystem, similar to the Acidobacteria.

Clone $\mathrm{H} 40$ was affiliated with candidate division TM7, which was one of several described bacterial divisions exclusively characterized by environmental sequence data. TM7 was originally proposed based on partial 16S rDNA sequences obtained from PCR clonal studies of a peat bog (Rheims et al. 1996). Their sequences have since been detected in diverse habitats, such as soils, rhizosphere, groundwater, seawater, deep-sea sediments, human oral cavity (Hugenholtz et al. 2001). But in previous research, they have not been found in an acidic environment. Furthermore, clone $\mathrm{H} 40$ had $91 \%$ similarity to its closest relative. Thus it may be a new member of candidate division TM7.

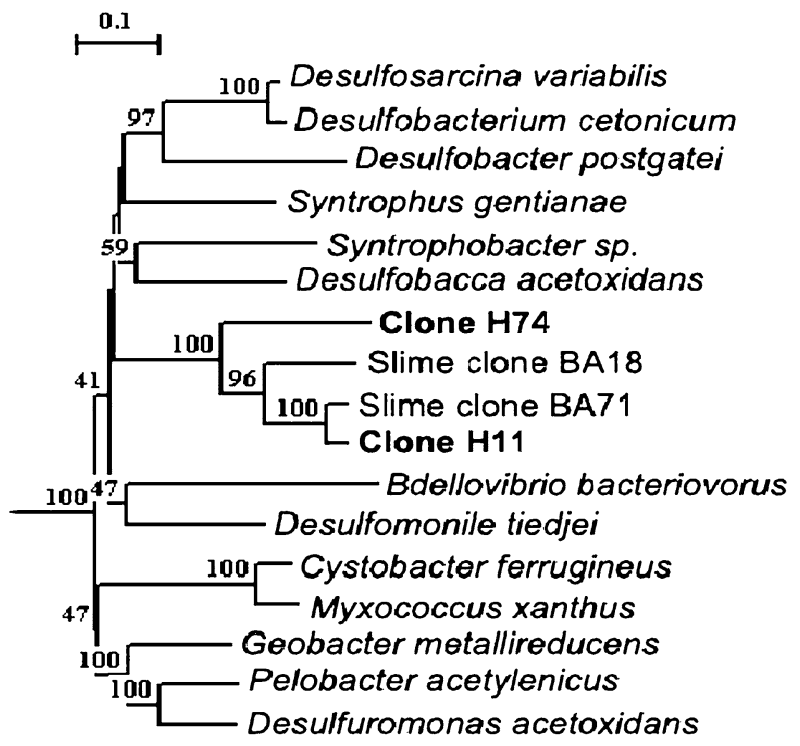

Fig. 3 Neighbour-joining phylogenetic tree from analysis $1.5 \mathrm{~kb}$ of $16 \mathrm{~S}$ rRNA gene sequences of $\delta$-Proteobacteria. Numbers at the node indicate bootstrap values of 1000 resampling. Desulfovibrio desulfuricans (not shown) was used as the outgroup. The scale bar represents changes per nucleotide. Database sequence accession numbers are as follows: Desulfosarcina variabilis, M34407; Desulfobacterium cetonicum, AJ237603; Desulfobacter postgatei, M26633; Syntrophus gentianae, X85132; Syntrophobacter sp. X94911; Desulfobacca acetoxidans, AF002671; Bdellovibrio bacteriovorus, M59297; Desulfomonile tiedjei, M26635; Cystobacter ferrugineus, AJ233901; Myxococcus xanthus, M34114; Geobacter metallireducens, L07834; Pelobacter acetylenicus, X70955; Desulfuromonas acetoxidans, M26634

\section{Discussion}

Based on the elemental analysis and X-ray diffraction (not shown) of the sediment, it could be concluded that the investigated sediment is a mixture of limonite, quartz and feldspar. Limonite is the oxidation product of other iron ore and distributed widely in nature, which usually contains lots of water. The dominant ore body of Xiang Mountain is pyrite (more than 90\%), which has been mined for more than 50 years. Mining operations cracked the soil and rock, which lead to an increased permeability and large numbers of unprocessed deposits. Most of the waste ores were deposited in the Nanshan refuse dump at Xiang Mountain, where we sampled the sediment. These activities have increased the sulfide mineral surface area and the total reactive ore that was exposed to oxygen and surface water. The exposed ore is oxidized by acidophiles and releases large amounts of $\mathrm{Fe}^{3+}, \mathrm{H}^{+}$and $\mathrm{SO}_{4}^{2-}$. These components seep down with water in close clearance of waste ore, then are deposited on the compact terrain and formed the type of sediment layers we studied. 


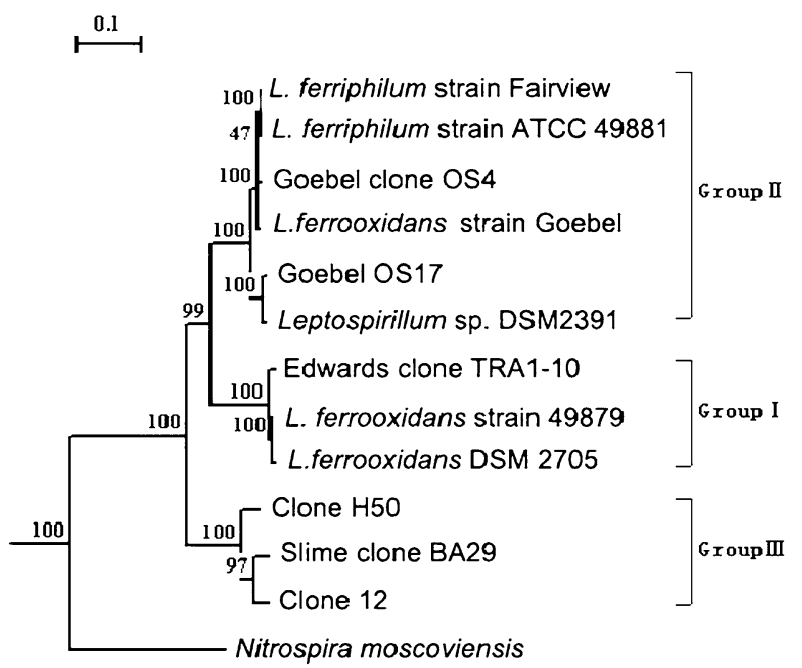

Fig. 4 Neighbour-joining phylogenetic tree from analysis $1.5 \mathrm{~kb}$ of 16S rRNA gene sequences of "Nitrospira" group sequences. Numbers at the node indicate bootstrap values of 1000 resampling. Cyclobacterium marinum strain DSM 745 was used as outgroup (not shown). The scale bar represents changes per nucleotide. Database sequence accession numbers are as follows: L. ferriphilum strain Fairview, AF356830; L. ferriphilum strain ATCC 49881, AF356829; Goebel clone OS4, X86770; L. ferrooxidans, X72852; Goebel clone OS4, X86772; Leptospirillum sp. DSM2391, M79383; Edwards clone TRA1-10, AF047641; L. ferrooxidans strain 49789, AF356832; L. ferrooxidans strain DSM 2705, X86776; Slime clone BA29, AF225448; Nitrospira moscoviensis, X82558

It is reasonable that Acidithiobacillus ferrooxidans, Leptospirillum and other related species were found in the acidic sediment. The dominance of the $\delta$-Proteobacteria in the acidic ecosystem, however, seems illogical, as these species are typically known to grow best under neutral $\mathrm{pH}$ conditions (Brown et al. 1993). Clones falling within the $\delta$-Proteobacteria may represent anaerobic sulfate-reducing bacteria (SRB), which use $\mathrm{SO}_{4}^{2-}$ as the final electron acceptor for the metabolism of organic substances, as sulfate reduction is the dominant physiological trait of this subdivision and the investigated sediment had a pungent smell like hydrogen sulphide. They could also be ironreducing bacteria, because many members of $\delta$-Proteobacteria, such as some members of the Geobacteraceae family, can utilize $\mathrm{Fe}^{3+}$ as an electron acceptor and conserve energy for growth via $\mathrm{Fe}^{3+}$ reduction in anaerobic conditions (Petrie et al. 2003). After long-term oxidation, most of the iron in the sediment is $\mathrm{Fe}^{3+}$ instead of $\mathrm{Fe}^{2+}$, which restrains the growth of iron-oxidizing acidophiles that are abundant in common acidic environment. In the process of oxidation, organic carbon such as cell exudates and lysates originating from the autotrophic acidophiles also accumulated to some extent. Furthermore, the high $\mathrm{SO}_{4}^{2-}$ and the anaerobic microenvironment, created by the compactness of the sediment, are all favorable conditions for sulfate- or iron-reducing bacteria, which may explain the high proportion of $\delta$-Proteobacteria in the sediment.

\section{Conclusion}

The present study indicates that the acidophiles in the acidic sediment are novel and related to Acidobacteria, $\beta / \gamma$-Proteobacteria, $\delta$-Proteobacteria, Nitrospira, Candidate division TM7, and Low G + C Gram-positives. The microbial community was dominated by bacteria of $\delta$-Proteobacteria, which have not been found in large quantities in such acidic environments before.

Acknowledgements This work was supported by the "Knowledge Innovation" (KJCX2-SW-206-4) Program of Chinese Academy of Sciences.

\section{References}

Bond PL, Smriga SP, Banfield JF (2000) Phylogeny of microorganisms populating a thick, subaerial, predominantly lithotrophic biofilm at an extreme acid mine drainage site. Appl Environ Microbiol 66:3842-3849

Brown DE, Groves GR, Miller JDA (1993) pH and Eh control of cultures of sulfate reducing bacteria. J Appl Chem Biotechnol 23:141-149

Edwards KJ, Goebel BM, Rodgers TM, Schrenk MO, Gihring TM, Cardona MM, Pace NR, Banfield JF (1999) Geomicrobiology of pyrite (FeS2) dissolution: case study at Iron Mountain, California. Geomicrobiol J 16:155-179

Edwards KJ, Bond PL, Gihring TM, Banfield JF (2000) An archaeal iron-oxidizing extreme acidophile important in acidic mine drainage. Science 287:1796-1798

Godon JJ, Zumstem E, Dabert P, Habouzit F, Moletta R (1997) Molecular microbial diversity of an anaerobic digestor as determined by small-subunit rDNA sequence analysis. Appl Environ Microbiol 63:2802-2813

Gomes NCM, Fagbola O, Costa R, Rumjanek NG, Buchner A, Mendona-Hagler L, Smallal K (2003) Dynamics of fungal communities in bulk and maize rhizosphere soil in the tropics. Appl Environ Microbiol 69:3758-3766

Golyshina OV, Pivovarova TA, Karavaiko GI, Kondrateva TF, Moore ER, Abraham WR, Lunsdorf H, Timmis KN (2000) Ferroplasma acidiphilum gen. nov., sp. nov., an acidophilic, autotrophic, ferrous-iron-oxidizing, cell-wall-lacking, mesophilic member of the Ferroplasmaceae fam. Nov. comprising a distinct lineage of the Archaea. Int J Syst Evol Microbiol 50:997-1006

Gonzalez-Toril E, Llobet-Brossa E, Casamayor EO, Amann R, Amils R (2003) Microbial ecology of an extreme acidic environment, the Tinto River. Appl Environ Microbiol 69:4853-4865

Hugenholtz P, Goebel BM, Pace NR (1998) Impact of cultureindependent studies on the emerging phylogenetic view of bacterial diversity. J Bacteriol 180:4765-4774 
Hugenholtz P, Tyson GW, Webb RI, Blackall LL (2001) Investigation of candidate division TM7: a recently recognized major lineage of the domain Bacteria with no known pureculture representatives. Appl Environ Microbiol 67:411-419

Johnson DB (1998) Biodiversity and ecology of acidophilic microorganisms. FEMS Microbiol Ecol 27:307-317

Kellner RLL (2002) Molecular identification of an endosymbiotic bacterium associated with pederin biosynthesis in $\mathrm{Pa}$ ederus sabaeus (Coleoptera: Staphylinidae). Insect Biochem Mol Biol 32:389-395

Orphan VJ, Hinrichs KU, Paull CK, Taylor LT, Sylva SP, Delong EF (2001) Comparative analysis of methane-oxidizing archaea and sulfate-reducing bacteria in anoxic marine sediments. Appl Environ Microbiol 67:1922-1934

Petrie L, North NN, Dollhpf SL, Balkwill DL, Kostka JE 2003 Enumeration and characterization of iron (III)-reducing microbial communities from acidic subsurface sediments contaminated with uranium (VI). Appl Environ Microbiol 69:7467-7479

Picard C, Cello FD, Venture M, Fani R, Gukert A (2000) Frequency and biodiversity of 2,4-diacetylphloroglucinol-producing bacteria isolated from the maize rhizosphere at different stages of plant growth. Appl Environ Microbiol 66:948-955

Rawlings DE (2001) The molecular genetics of Thiobacillus ferrooxidans and other mesophilic, acidophilic, chemolithotrophic, iron- or sulfur-oxidizing bacteria. Hydrometallurgy 59:187-201
Rheims H, Rainey FA, Stackebrandt E (1996) A molecular approach to search for diversity among bacteria in the environment. J Ind Microbiol 17:159-169

Rojas-Chapana JA, Tributsch H (2001) Biochemistry of sulfur extraction in bio-corrosion of pyrite by Thiobacillus ferrooxidans. Hydrometallurgy 59:291-300

Sambrook J, Russell DW (2001) Molecular cloning: a laboratory manual. Cold Spring Harbor Laboratory Press, Cold Spring Harbor, New York, pp 84-824 (ISBN 0-87969-576-5)

Schrenk MO, Edwards KJ, Goodman RM, Hamers RJ, Banfield JF (1998) Distribution of Thiobacillus ferrooxidans and Leptospirillum ferrooxidans: implications for generation of acidic mine drainage. Science 279:1519-1522

Watanabe K, Kodama Y, Syutsubo K, Harayama S (2000) Molecular characterization of bacterial populations in petroleum-contaminated groundwater discharged from underground crude oil storage cavities. Appl Environ Microbiol 66:4803-4809

Watanabe K, Kodama Y, Hamamura N, Kaku N (2002) Diversity, abundance, and activity of archaeal populations in oilcontaminated groundwater accumulated at the bottom of an underground crude oil storage cavity. Appl Environ Microbiol 68:3899-3907

Zhou JZ, Bruns MA, Tiedje JM (1996) DNA recovery from soils of diverse composition. Appl Environ Microbiol 62:316-322 